\title{
Development of Nutrition Learning Models for Elementary School Children in Kendari
}

\author{
RISMA, MASRIF and E NURLAELA \\ Poltekkes Kemenkes Kendari Jl. Jend. A.H. Nasution No. G.14 Anduonohu, Kendari, Indonesia 93232
}

(Received June 23, 2019)

\begin{abstract}
Summary A nutrition learning model themed "Makananku Sehat dan Bergizi" was aimed for fourth-grade students of elementary school who used the K13 Curriculum K13 that was developed in 2013. The model accommodated the old version of nutrition concept and they were delivered withconventional model. This study aimed to design a new learning model and to discover effect of themodel on nutritional knowledge and behavior of elementary school children in Kendari. Thisstudy was a quasi experimental study using one group with pre-post test design. This study was held in 2017 in Puuwatu district, Kendari. The subjects were 15 fourth-grade teachers and 60 elementaryschool students from SD 05 Mandonga. Data related to knowledge and behavior of the students werecollected and analyzed. The pre- and post-nutrition learning models were analyzed by interview using a questionnaire. Data were statistically tested using paired $t$-test. Learning model that was developedwas named Model Pembelajaran Gizi Kontekstual or CTL (Contextual Teaching and Learning). There was significant improvement in terms of nutritional knowledge and behavior of the studentsbefore and after introduction to a song titled Kebiasaan Makanku and to a flipchart themed Mengenal Jenis dan Manfaat Makanan. There is a need for nutrition education for elementaryschool teachers, especially for the fourth grade. Thus, teachers would have good knowledge onnutrition and therefore, they could use it to educate their students. Eventually, it would helpimplementation of CTL model.
\end{abstract}

Key Words nutrition learning model, elementary school children

Nutrition education for elementary school children is very necessary because it has a great opportunity to achieveimprovement knowledge about nutrition among the community particularly forelementary school childrenwhich are expected to be a bridge for teachers to reach their parents and environment. Besides that School Age Children are also the most important target of nutrition education related eating habits in childhood while can affect food preferences and consumption in later life (1). In the thematic-based elementary school education curriculum in Indonesia (2013 curriculum), nutritionsubject has become a part of the education that must be given to fourth grade elementary school students, whichitscontent such as Healthy and Nutritious Foods, Benefits of Healthy and Nutritious Foods and Healthy Eating Habits (2).

Acceptance ability of student in nutrition subject is very dependent on such as knowledge of the teacher about nutrition itself, so that it can be said that the level of knowledge of the teacher will affect the student itself. The problem found in elementary school teachers is that most of teachers do not understand about nutrition, still provide nutrition subjectusing an old concepts with conventional ones, delivered only by lecture method. If this conditions are allowed, effective and efficient learning objectives will not be achieved. For that, qualified teachers are needed, who master various

E-mail: rismasake@gmail.com approaches, strategies, models and learning methods so that they can manage optimal learning activities in various student situations and learning subject (3).

\section{MATERIALS AND METHODS}

Type of thisstudy is analytic survey with quasi-experimental design using one group pre post test model. This study was carried out in 2017 in Public Elementary Schools that have used the K13 curriculum and are located in the Puwatu sub-district of Kendari City. The sample of this study was 15 elementary school teachers in Puwatu district and 60 elementary school children inSD 05 Mandonga. Sampling of elementary school teachers and students are done by total sampling technique. The data collected includes data analysis identifying the need for design learning models of nutritional subjects, and was obtained through interviews using questionnaires by elementary school teachers. Knowledge and attitudesdata toward nutrition subject were obtained by interviews using questionnaires on elementary school children. Beforethe instrument is usedfor data collection, the validity and reliability was conducted and processed using SPSS 18. Based on the results of the trial, the reliability coefficient was 0.988 . Data identification analysis needs of learning model design is processed through descriptive and thematic analysis in accordance with the results of teacher interviews and findings in the field and data on differences in knowledge and attitudes of elementary children before 
and after the application of nutritional material learning models were analyzed using statistical tests Paired sample $t$-test Dependent using computer in the SPSS 11.5 program for windows. This research was conducted based on ethical approval from the ethics committee of the Ministry of Health of Jogjakarta with the letter No. L.B.01.01/KE-01/XXXVI/797/2017.

\section{RESULTS}

\section{Model design requirement analysis}

From the results of interviews with elementary school teachers, most of the teachers (74 persen) in teaching nutrition subjectswas still using the lecture or conventional methods, most teachers (86 persen) lacked understanding of the nutrition subject being taught. Most of teachers (76 persen) do not use a media. Most teachers (78 persen) suggest using learning models that are relevant to everyday life or applicable. Most teachers (80 persen) need media to deliver nutrition subject, and most teachers suggest that there are related parties who provide education about nutrition.

Based on qualitative interviews and analysis of the needs identification of the learning model of nutrition subject from several existing learning models, the learning model that needs to be developed for grade IV elementary school children is the Contextual Nutrition Learning Model (CTL). CTL Learning Model (Contextual Teaching and Learning) is a holistic educational process and aims to motivate students to understand the meaning of the learning subjects they learn by linking the material to the context of their daily lives (personal, social, and cultural context) so that students have knowledge/skills that can be flexibly applied (transferred) from one problem to another. The Contextual Learning Model (CTL) that will be developed in the provision of nutritional subject for 4th grade elementary school children will be provided using audio and visual media. The learning media that will be used are different for each sub-nutrition subject that has been contained in the book, as follows: (1) Sub-themes of nutritional material "My eating habits" are taught with the TLC model using Media Audio in the form of "My Habits" and (2) sub the theme of nutritional material "Getting to know the types and benefits of food nutrients is taught with the TLC model using visual media in the form of flipcharts. Overall the process of making two (2) media includes the stage of determining themes or lyrics to the mixing process for children's song media and printing for flipchart media. In determining the theme or lyrics in both media, it is adjusted to the content of the material contained in the textbook and the message of nutrition that you want to convey.

Differences before and after application of contextual learning models using media songs "Kebiasaan Makanku"

The measurement results of students' knowledge and attitudes before and after the application of song-based contextual learning models are as follows.

Table 1 shows average score of sample for nutrition knowledge before the application of the song media
Table 1. Application of the Contextual Learning Model by Using the Song Media "Kebiasaan Makanku".

\begin{tabular}{lrrrr}
\hline Variable & Mean & SD & SE & $p$ value \\
\hline Knowledge & & & & \\
Before & 76.7 & 12.91 & 1.7 & $0.004^{*}$ \\
After & 82.9 & 13.41 & 1.7 & \\
\hline Attitude & & & & \\
Before & 72.1 & 14.62 & 1.9 & 0.051 \\
After & 75.0 & 9.20 & 1.2 & \\
\end{tabular}

Table 2. Application of the Contextual Learning Model Using Flipchart Media "Mengenal Jenis dan Manfaat zat zat gizi makanan".

\begin{tabular}{lcccc}
\hline Variable & Mean & SD & SE & $p$ value \\
\hline $\begin{array}{l}\text { Knowledge } \\
\text { Before }\end{array}$ & 54.83 & 12.41 & 1.60 & $0.000^{*}$ \\
After & 74.17 & 20.69 & 2.67 & \\
\hline Attitude & & & & \\
Before & 82.00 & 14.12 & 1.82 & $0.000^{*}$ \\
After & 93.33 & 10.84 & 1.39 & \\
\hline
\end{tabular}

contextual learning model is 76.67 with a standard deviation of 12.91 . to 82.92 with Standard Deviation of 13.41 . The results of the statistical test obtained a value of 0.004 so it can be concluded that there is a significant difference between the nutritional knowledge of the sample before and after the application of the media contextual learning model of the song "Kebiasaan Makanku". The average sample attitude score before the application of the song media contextual learning model is 72.08 with a standard deviation of 14.62 . After applying the average model of knowledge it increases to 75.00 with a Standard Deviation of 9.20. The results of statistical tests obtained a value of 0.051 , it can be concluded that there was no significant difference between the attitude of the sample before and after the application of the media contextual learning model the song "Kebiasaan Makanku".

Differences before and after the application of contextual learning models by using flipchart media "Mengenal Jenis dan Manfaat Makanan"

The results of students' knowledge and attitudes before and after the application of contextual learning models with Flipchart media are as follows.

Table 2 shows average score of knowledge before the application of the Flipchart Media contextual learning model was 54.83 with a standard deviation of 12.41 . After applying it, the average score increased to 74.17 with a Standard Deviation of 20.69. The statistical test results obtained a value of 0,000 , it can be concluded that there is a significant difference between the knowledge before and after the application of the Flipchart 
Media contextual learning model "Mengenal Jenis dan Manfaat Makanan".

The average sample attitude score before the application of the Flipchart Media contextual learning model is 82.00 with a standard deviation of 14.21 . After applying themodel, attitude average score increased to 93.33 with a Standard Deviation of 10.84 . The statistical test results obtained a value of 0,000 , it can be concluded that there is a significant difference between the attitude of the sample before and after the application of the Flipchart Media contextual learning model "Mengenal Jenis dan Manfaat Makanan".

\section{DISCUSSION}

From the results of the study, it was found that the learning model developed in delivering nutritional material for fourth grade elementary school children was a Contextual Learning (CTL) model, the concept of learning and teaching that helped teachers associate the material taught with students' real world situations and encourage students to make connections between knowledge with application in their daily lives. In applying the contextual learning model, media is an important component that must be prepared. Unconducivemedialearningsuch as whiteboard media will create a less learning atmosphereso this will cause them to be unable to develop new findings that are more in line with the needs of the real world. The results showed that there were significant differences in knowledge and attitudes before and after the application of the "Kebiasaan Makanku" and Media Flipchart Song Learning Media models "Mengenal Jenis dan Manfaat Makanan". The significant difference of this study is probably caused by one of them students are very interested in the contextual learning model that is applied by using cheerful song media and flipchart media that are full of interesting writing and images. The results of this study are in line with other studies which concluded that the use of media cartoon art-based contextual learning models had a greater influence in improving social studies learning outcomes of grade 3 students of SD Aisyiyah Unggulan Gemolong (5).

This study is also in accordance with the research in Bogor Regency which found that there were significant differences in knowledge and attitudes after the intervention using a combination of video, flip chart and brochure media (6). Several studies on nutritional education report that various methods of nutritional education have different effects on nutrition knowledge and attitudes. Flip charts have long been used as an intervention medium and have been proven to improve knowledge well. Using a good flip chart can improve participants' knowledge and attitudes well (7). This is in accordance with statement that visual media can facilitate understanding and strengthen memory. Visual media can also foster student interest and can provide a connection between the content of subject matter and the real world (8). Visual stimulation given to someone can contribute to the absorption of material by 30 persen, compared to reading text which only contrib- utes 10 persen (9).

Children aged 7-10 y are in the stage of fostering attitudes towards themselves, groups or communities, learning to play a role and awareness of their own abilities, so that knowledge and attitudes will be more easily changed by providing methods and media that suit their needs (10).

Other research about the Contextual learning model in junior high school students, where the results have a positive influence on the Contextual Teaching and Learning Model for Social Science learning outcomes from the Earth Form material in VII grade students of junior high school (11).

Previous research (12) applied the Learning Cycle 5-E learning model to students in understanding nutrient analysis material. Learning Cycle Learning Model 5-E is a constructivist-based learning model that is widely used because each learning phase helps students to connect previously owned knowledge with new knowledge, so as to avoid misconceptions and better concept understanding. This model is appropriate if applied to students where students are individuals who already have a better mindset. However, the Learning Cycle 5-E learning model is not appropriate enuogh when applied to elementary school children (SD) where they still really need a more tangible or contextual explanation to help their understanding. Therefore we are doing research on contextual learning models or CTL (Contextual Teaching and Learning) with Song and Flipchart media in delivering nutrition material to elementary school children.

The application of the Contextual Nutrition Learning Model with Song and Flipchart Media can improve knowledge and attitudes about nutrition for elementary school children. Good nutrition knowledge can influence the attitudes and nutritional practices of children in their daily lives, so that it can affect their intake and nutritional needs of children will be met and ultimately will affect children's health.

In this study the application of the contextual learning model (CTL) to elementary school students was not done directly by the teacher because the existing grade IV elementary school teachers did not understand nutrition well. Therefore, it is recommended that the teacher as the provider of nutritional material for elementary school children must have an understanding of nutrition in applying media-based CTL learning methods so that in teaching nutritional material to students, the teacher already understands nutrition so that it can apply the CTL Model well.

\section{Disclosure of state of COI}

There is no conflict of interests.

\section{Acknowledgments}

The author would like to thank the Health Ministry of Health Polytechnic of Kendari who have funded this research. Teachers and students of Elementary school 05 Mandonga in Kendari City, Southeast Sulawesi, Indonesia for their cooperation in this study. 


\section{REFERENCES}

1) Santoso. 2012. Kesehatan dan Gizi. Jakarta Rhineka Cipta.

2) Kementerian Pendidikan dan Kebudayaan, 2013. Makananku Sehat dan Bergizi. Jakarta. Lazuardi GIS.

3) Daryanto. 2011. Media Pembelajaran. Bandung: Sarana Tutorial Nurani Sejahtera.

4) Dirjen Dikdasmen Depdiknas RI. 2002 Pendekatan Kontekstual (Contextual Teaching and Learning (CTL). Jakarta: Ditjen Dikdasmen Depdiknas.

5) Abdullah F. 2015. Implementasi Model Pembelajaran Kontekstual Berbasis Cartoon Art Terhadap Hasil Belajar IPS Siswa Kelas 3 SD Aisyiyah Unggulan Gemolong Tahun Ajaran 2014/2015. Skripsi thesis, Universitas Muhammadiyah Surakarta.

6) Ekayanti I, Briawan D, Destiara I. 2013. Perbedaan Penggunaan Media Pendidikan Terhadap Perubahan Pengetahuan dan Sikap Ibu Dalam Sarapan Anak Sekolah Dasar di Kabupaten Bogor. Jurnal Gizi dan Pangan 8(2): 109-114.

7) Sharan S. 2014. Handook of Cooperative Learning Methods. Terjemahan Sigut Prawoto. Yogyakarta: Istana Media.
8) Ahmad S. 2005. Strategi Belajar Mengajar. Jakarta. Ciputat Press.

9) Contento IR. 2011. Nutrition Education: Linking Research, Theory, and Practice (2nd ed). Sudbury, MA: Jones and Bartlett.

10) Arsyad. A. 2009. Media Pembelajaran. Jakarta. Rajawali Press.

11) Surdin. 2018. The Effect of Contextual Teaching and Learning (CTL) Models on learning outcomes of Social Sciences of the material of forms the face of the earth on Class VII of Junior High School. International Journal of Education and Research 6 (3).

12) Setyorini. 2017. Pembelajaran Analisis Zat Gizi Dengan Model Learning Cycle 5-E. Darussalam Nutrition Journal 1(1): 22-33.

13) Bybee RW, Taylor JA, Gardner A, Scotter PV, Powell JC, Westbrook A, danLandes N. 2006. The BSCS 5E Instructional Model: Origins and Effectiveness. Colorado Springs: Office of Science Education National Institute of Health, (Online), (http://www.science.education.nih. gov/houseofreps.nsf/b82d 55 fa138783c2852572 c9004f5566/\$FILE/Appendix\%20D.pdf), diakses2 Februari 2020. 